\title{
Unearthing the International Financial Reporting Standards (IFRS) in the Accounting Curriculum in Saudi Arabia - An Empirical Study
}

\author{
Mohammed Alfify \\ College of Business Administration, Jazan University, Saudi Arabia \\ Abdul Ghani Faiyyaz (Corresponding author) \\ College of Business Administration, Jazan University, Saudi Arabia \\ E-mail: afayyaz@jazanu.edu.sa \\ Abdullah Malik \\ Quantum School of Business, Quantum University, Roorkee, India
}

Received: April 3, 2021

Accepted: April 22, 2021

Published: May 24, 2021

doi: 10.5296/ijafr.v11i2.18492

URL: https://doi.org/10.5296/ijafr.v11i2.18492

\begin{abstract}
International Financial Reporting Standards, commonly known as IFRSs, are uniform accounting standards issued by the International Accounting Standards Board (IASB) in 2001. The Saudi Organization for Certified Public Accountants (SOCPA) from 1st Jan 2016 has announced its decision to converge their National Accounting Standard with IFRS. The standards will surely be going to influence the financial system of the country. Every country has its own Generally Accepted Accounting Principles (GAAP). However, an understanding is needed to evaluate the adoption and awareness of IFRS among students and academicians in Saudi Arabia. The present study attempted to examine the awareness and interest of students concerning IFRS. This study has brought some hard facts regarding IFRS convergence in Saudi Arabia. The IFRS will only be able to yield fruitful results when all stakeholders are fully aware, interested, taken into confidence, and ready to cooperate with the directives of the Saudi Organization for Certified Public Accountants (SOCPA) for IFRS adaption.
\end{abstract}

Keywords: IFRS, GAAP, SOCPA, IAS, Accounting curriculum 


\section{Introduction}

The International Accounting Standards (IAS) is an older accounting standard. From 1973 to 2001, International Accounting Standard Committee (IASC) published, International Accounting standard (IAS). International Accounting standards used to have total IAS 1 to IAS 40 Standard. However, in the year 2001 IAS has been replaced by International Financial Reporting Standard (IFRS), and the International Accounting standard Board has started publishing IFRS, which contains a total IFRS 16 standard. Therefore, the IFRS not new instead its replacement of IAS. Due to globalisation and countries opening their trade boundaries for other countries with certain restrictions. A need has been felt to have refined and unified accounting standards of reporting its financial statements, which would have acceptability and applicability across the boundaries. In this backdrop, IFRS has been envisaged by International Accounting Standard to panaceas for multinational Corporations' financial reporting problems (MNCs). IFRS is more robust than the International Accounting standard (IAS). IFRS has brought Comparability, Verifiability, Timeliness, Understandability, Acceptability, and uniformity in financial reporting across the globe. Ever Since the Introduction of IFRS by International Accounting standard Board (IASB), many countries started adopting IFRS in total. At the same time, some countries prepared their national accounting standard in line with IFRS. For Example, India, In continuance with the International trend, the Institute of Chartered Accountants of India (ICAI) has proposed a plan for convergence with IFRS for certain defined entities (listed entities, banks and insurance entities and certain other large-sized entities) with effect from accounting periods commencing on or after 1st April 2011 named Indian Accounting Standard (Patro and Gupta, 2012).

Due to its peculiarities and unprecedented recompenses of IFRS, Saudi Arabia also visualises the need to adapt IFRS. Because of the increasing importance of IFRS, the majority are acknowledged on the requirement to embrace IFRS in Saudi Arabia, which requires Saudi Universities to include and demonstrate IFRS (Motairy and Torky, 2012). In an era of globalisation of trade \& commerce the Saudi Arabia cannot afford to remain aloof from going to transition. Consequently, in congruence with the world order, the Saudi Organization for Certified Public Accountants (SOCPA) has also decided to converge their national accounting standard with International Financial Reporting Standards (IFRSs) in Kingdom of Saudi Arabia. The transition date to IFRS for listed companies was from $1^{\text {st }}$ Jan 2016 and the reporting date for the same was $31^{\text {st }}$ Dec 2017. While the transition date to IFRS for unlisted companies was from $1^{\text {st }}$ Jan 2017 and the reporting date for the same was $31^{\text {st }}$ Dec 2018 in Saudi Arabia.

Whether the acceptance of IFRS by the Saudi Arabia will incur more perceived cost than benefit, Benefit derived from IFRS adoption in Saudi Arabia will be more than the costs (Nurunnabi, 2018). The government's adoption of IFRS will be fruitful only when all stakeholders are interested and aware of the expected benefit of IFRS. Government intent, preparedness and lack of infrastructure, qualified accounting professionals, and awareness among students can hamper IFRS implementation. There is shortage of skilled accountants, substantial dependence on Big 4 accounting firms, limited exposure of IFRS in university 
education, and absence of research are identified as major obstacles to implementing IFRS in Saudi Arabia (Nurunnabi, 2018).

Although the initial training for IFRS may come from the Saudi Organization for Certified Public Accountants (SOCPA) and other international accounting firms. It is the management schools and universities that will have to ring the bell in this regard. Because a new breed of learners must be acquainted with IFRS, if students are interested and aware of IFRS transition, the objective behind IFRS transition can easily be achieved. The SOCPA and universities have to plan how to integrate IFRS into the accounting curriculum. Training, awareness, knowledge, and interest of IFRS will be indispensible to alignment. Moreover, Universities adopting IFRS in their course will have to select appropriate teaching methodology to get sought results. This research's primary objective is to investigate the interest and awareness of graduate students regarding the IFRS transition at the Jazan region in Saudi Arabia. By undertaking this study, we want to examine how far students are aware of the IFRS transition and how much they are interested in taking up this course in the future. This research will open many avenues for Saudi universities and suggest the pros and cons and need to adopt IFRS in their Accounting curriculum. At the same time, designing a course for Accounting and Management Students in the region.

\section{Review of Literature}

A literature review is considered as an integral part of any research study. Through this review, an effort would be made to have an insight into the work done so far and also the specific aspect IFRS particular in Saudi Arabia.

Elhaj(2019) has opined that Zakat rules are the most challenging aspect for SMEs for IFRS convergence in Saudi Arabia. SOCPA should prepare Zakat rules that are clearer and robust. A study conducted by Deloitte in Saudi Arabia in 2016 Entitled "Getting it right Adoption of IFRS in Saudi Arabia" highlighted that Saudi Arabia is going to Adopt IFRS for all Corporations except Bank and Insurance which will be governed by Saudi Arabian Monetary Authority (SAMA).However, the study finds the challenges in adoption as the number of Saudi qualified accountants is as low as 300. Arabic Language criteria pose another challenge and Compliance with Sharia or Local law of the country. Finally, the study suggests that these gaps can be reduced with careful planning and preparations by the corporation and extensive education in school and universities through target allocated resources. There is a significant difference between Saudi GAAP and IFRS standards (Nurunnabi, 2017). The IFRS adoption is expected to impact many aspects, including rules, regulating bodies, structures, processes, financial outcomes, education systems, and people's perception (Alshuhaibani, 2012). Adaptation to IFRS leads to a substantial decrease in net income of the firm.Further, there is an important difference in the index values across the various sectors (Razak and Alquraishi, 2019). Alkhtani (2012) had examined that IFRS adoption will result in more cost than benefit for small companies, but for Big Firms, adoption found to be advantageous. The study further suggested that IFRS adoption will enhance the quality of financial reporting. The IFRS in Saudi Arabia will result in more gain than pain (Nurunnabi, 2018; Alkhtani, 2012). 


\section{Mll Macrothink}

International Journal of Accounting and Financial Reporting ISSN 2162-3082 2021, Vol. 11, No. 2

The International Financial Reporting Standards (IFRSs) adoption by a country will lead to increase in Foreign Direct Investments (FDIs) inflow (Gorden et al., 2012; Okpala, 2012; Yousufinejad et al., 2018; Nnadi and Soobaroyen, 2015; Adetula et al., 2014; Akisik, 2014; Cheng et al,2014; Defond, 2010). The International Financial Reporting Standards (IFRSs) convergence by the countries will improve transparency, Comparability of financial reporting (Patel and shah 2015; Mahmood et al. 2018; Alghamdi 2014). Developing countries embracing IFRS will find it easy to get loan \& advances and financial aid from World Bank (Gorden et al, 2012).IFRS adoption by emerging economies will also lead to increased earning quality by corporations (Ismail et al., 2010).

After critically examining previous studies on the International financial reporting standard. It can be said that though there are various studies conducted on IFRS across the globe. However, previous studies fail to address International Financial Reporting Standards (IFRS) in the Accounting Curriculum in Saudi Arabia. In this backdrop, this study has been undertaken to address this gap which previous studies lacks in Saudi Arabian Context. The present study is an attempt to fill this emerging gap and devoted to making an analytical evaluation of International Financial Reporting Standards (IFRS) in the Accounting Curriculum in Saudi Arabia.

\section{Research Questions}

Based on the above studies of Literature reviewed, the following research questions have been formulated that needed to be addressed before adopting International Financial Reporting Standards to the Saudi Universities Accounting curriculum.

RQ1-Is there any need for IFRS to be introduced in the Saudi Arabian Universities?

RQ2- Do Saudi Arabian Graduate students have any knowledge of IFRS?

RQ3-Do Saudi students have any interest in electing IFRS course in their curriculum?

RQ4-If students are enthusiastic about taking IFRS in their course, what teaching methodology would they prefer for taking up the course?

RQ5-What would be the probable effect after adopting IFRS to the Saudi GAAP Accounting curriculum?

RQ6-Are Universities in Saudi Arabia ready and well equipped to adopt IFRS to its Curriculum?

\section{Research Methodology}

The research was based mainly on primary data. The adapted questionnaire (Patro and Gupta, 2012) was utilised with sample size $(n=135)$ for the purpose of the research. As in the adapted questionnaire, the items are changed as per the demographic and cultural basis. The questionnaire's design, pattern, and structure have been simple, study-specific, unambiguous, minimal, and capable of invoking the objective type of answers by marking a tick only on the statement which students consider fit as per their agreement and disagreement. The researchers distributed the questionnaire through Google survey forms to the students of 


\section{Ml Macrothink}

International Journal of Accounting and Financial Reporting ISSN 2162-3082 2021, Vol. 11, No. 2

business colleges at Jazan region in Saudi Arabia. The sample consists of the most diversified student groups' accounting, finance and allied courses. The respondents returned the filled questionnaires. The research was performed with a sample of 135 respondents after eliminating half-finished responses. Relevant statistical tools have been employed to analyse collected data. The study mainly measured attitudes to the increased merging of Saudi accounting principles with global standards, how they would view the prospect of a common set of accounting standards in Saudi Arabia and the accounting curriculum and the degree of preparedness for these possible developments.

\section{Data Analysis and Discussions}

\subsection{Sample Profile}

Table 1. Sample profile

\begin{tabular}{cll}
\hline Gender & Male & 81 \\
& Female & 54 \\
\hline Age (years) & $18-21$ & 68 \\
& $22-25$ & 67 \\
\hline Marital status & Married & 56 \\
& Unmarried & 79 \\
\hline Education & Under - graduate & 135 \\
\hline Specialisation & Accounting & 88 \\
& Finance & 33 \\
& Management Information System & 14 \\
\hline Occupation & & 135 \\
& Student & \\
\hline
\end{tabular}

Source: Primary Data

\subsection{Question Wise Analysis}

a) What do you envisage by the word"One Accounting in World"?

Table 2. Showing the understandably by One Accounting in World

\begin{tabular}{lcrrr}
\hline & Frequency & Percent & Valid Percent & $\begin{array}{c}\text { Cumulative } \\
\text { Percent }\end{array}$ \\
\hline Saudi GAAP & 76 & 56.3 & 56.3 & 56.3 \\
\hline US GAP & 18 & 13.3 & 13.3 & 69.6 \\
\hline IFRS & 41 & 30.4 & 30.4 & 100.0 \\
\hline Source: Primary Data & & & & \\
\hline
\end{tabular}


b) Have you ever heard about IFRS?

Table 3. Have you ever heard about IFRS?

\begin{tabular}{lrrrr}
\hline & Frequency & \multicolumn{1}{c}{ Percent } & Valid Percent & \multicolumn{2}{c}{$\begin{array}{c}\text { Cumulative } \\
\text { Percent }\end{array}$} \\
\hline Yes & 120 & 88.9 & 88.9 & 88.9 \\
\hline No & 15 & 11.1 & 11.1 & 100.0 \\
\hline
\end{tabular}

Source: Primary Data

c) Information regarding IFRS

Table 4. Showing the source of information regarding IFRS

\begin{tabular}{lrrrr}
\hline & Frequency & Percent & Valid Percent & \multicolumn{2}{c}{$\begin{array}{c}\text { Cumulative } \\
\text { Percent }\end{array}$} \\
\hline Newspaper & 21 & 15.6 & 15.6 & 15.6 \\
\hline Magazines & 35 & 25.9 & 25.9 & 41.5 \\
\hline Classroom Session & 31 & 23.0 & 23.0 & 64.4 \\
\hline Internet & 48 & 35.6 & 35.6 & 100.0 \\
\hline
\end{tabular}

Source: Primary Data

d) Are you aware that SOCPA has adopted IFRS in Saudi Arabia from 2016 for Listed Companies?

Table 5. Showing the awareness towards the Saudi Organization for Certified Public Accountants (SOCPA), has adopted IFRS in Saudi Arabia from 2016 for Listed Companies?

\begin{tabular}{|c|c|c|c|c|}
\hline & Frequency & Per cent & Valid Percent & Cumulative Percent \\
\hline Yes & 96 & 71.1 & 71.1 & 71.1 \\
\hline No & 39 & 28.9 & 28.9 & 100.0 \\
\hline
\end{tabular}

Source: Primary Data

e) Are you acquainted with the Basic differences between Saudi Arabia GAAP and IFRS?

Table 6. Showing the awareness of key differences between Saudi Arabia GAAP and IFRS?

\begin{tabular}{|c|c|c|c|c|}
\hline & Frequency & Percent & Valid Percent & Cumulative Percent \\
\hline Yes & 113 & 83.7 & 83.7 & 83.7 \\
\hline No & 22 & 16.3 & 16.3 & 100.0 \\
\hline
\end{tabular}

Source: Primary Data

f) Have you taken any training on IFRS? 


\section{Macrothink \\ International Journal of Accounting and Financial Reporting ISSN 2162-3082 2021, Vol. 11, No. 2}

Table 7. Showing the students taken training on IFRS?

\begin{tabular}{|c|c|c|c|c|}
\hline & Frequency & Percent & Valid Percent & Cumulative Percent \\
\hline Yes & 110 & 85.2 & 85.2 & 85.2 \\
\hline No & 25 & 14.8 & 14.8 & 100.0 \\
\hline
\end{tabular}

Source: Primary Data

g) Are you curious to take training on IFRS in the near future?

Table 8. Showing the students' interest to take training on IFRS in the near future?

\begin{tabular}{|c|c|c|c|c|}
\hline & Frequency & Percent & Valid Percent & Cumulative Percent \\
\hline Yes & 97 & 71.9 & 71.9 & 71.9 \\
\hline No & 38 & 28.1 & 28.1 & 100.0 \\
\hline
\end{tabular}

Source: Primary Data

h) Does your course curriculum include IFRS

Table 9. Showing the information about the course curriculum of IFRS

\begin{tabular}{|c|c|c|c|c|}
\hline & Frequency & Precent & Valid Percent & Cumulative Percent \\
\hline Yes & 115 & 85.2 & 85.2 & 85.2 \\
\hline No & 20 & 14.8 & 14.8 & 100.0 \\
\hline
\end{tabular}

Source: Primary Data

i) Should universities implement IFRS in their course curriculum?

Table 10. Showing the information about Should universities adopt IFRS in their course curriculum or not

\begin{tabular}{|c|c|c|c|c|}
\hline & Frequency & Percent & Valid Percent & Cumulative Percent \\
\hline Yes & 123 & 91.1 & 91.1 & 91.1 \\
\hline No & 12 & 8.9 & 8.9 & 100.0 \\
\hline
\end{tabular}

Source: Primary Data

j) IFRS should be implemented in the curriculum of 


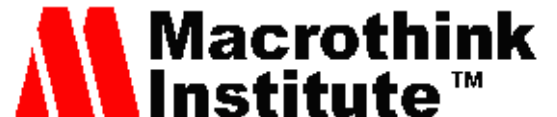

International Journal of Accounting and Financial Reporting ISSN 2162-3082

Table 11. Showing whether the IFRS should be introduced in the curriculum of different courses

\begin{tabular}{lcccc} 
& Frequency & Percent & Valid Percent & $\begin{array}{c}\text { Cumulative } \\
\text { Percent }\end{array}$ \\
\hline PG core course & 65 & 48.1 & 48.1 & 48.1 \\
\hline Course independent Study & 31 & 23.0 & 23.0 & 71.1 \\
\hline Elective course & 1 & .7 & .7 & 71.9 \\
\hline Project work & 38 & 28.1 & 28.1 & 100.0 \\
\hline
\end{tabular}

Source: Primary Data

\section{k) Will the Knowledge of IFRS be helpful in your future Job}

Table 12. Showing that whether the Knowledge of IFRS be helpful in the students placement or not

\begin{tabular}{|c|c|c|c|c|}
\hline & Frequency & Percent & Valid Percent & Cumulative Percent \\
\hline Yes & 117 & 86.7 & 86.7 & 86.7 \\
\hline No & 18 & 13.3 & 13.3 & 100.0 \\
\hline
\end{tabular}

Source: Primary Data

\section{I) Is Saudi Arabia ready with enough competent, Experts or CAs to adopt IFRS}

Table 13. Showing whether the institute in Saudi Arabia is ready with enough competent, Specialists or CAs to adopt IFRS

\begin{tabular}{|c|c|c|c|c|}
\hline & Frequency & Percent & Valid Percent & Cumulative Percent \\
\hline Yes & 91 & 67.4 & 67.4 & 67.4 \\
\hline No & 44 & 32.6 & 32.6 & 100.0 \\
\hline
\end{tabular}

Source: Primary Data

m) What teaching method would you prefer for IFRS education

Table 14. What teaching method would you prefer for IFRS education?

\begin{tabular}{lccrr} 
& Frequency & Percent & Valid Percent & Cumulative Percent \\
\hline Lecture & 68 & 50.4 & 50.4 & 50.4 \\
\hline Seminar & 37 & 27.4 & 27.4 & 77.8 \\
\hline Case study & 30 & 22.2 & 22.2 & 100.0 \\
\hline
\end{tabular}

Source: Primary Data

n) Would you like to choose IFRS as a course in your curriculum in future? 
Table 15. Would you like to choose IFRS as a course in your curriculum in future?

\begin{tabular}{|c|c|c|c|c|}
\hline & Frequency & Percent & Valid Percent & Cumulative Percent \\
\hline Yes & 112 & 83.0 & 83.0 & 83.0 \\
\hline No & 23 & 17.0 & 17.0 & 100.0 \\
\hline
\end{tabular}

Source: Primary Data

\section{Data Analysis and Interpretation}

\section{Descriptive Statistics for Learning of IFRS Knowledge and Skills and more information about IFRS}

The students' perception of the IFRS was analysed by using the mean and standard deviation on the 5 point scale data. The learning of IFRS knowledge and expertise will help in business transaction indicated the mean value of 3.6000 and standard deviation as 1.06645, which indicates that the students are relatively eager to learn IFRS and they want to gain the knowledge and skills that will help in recording the business transactions. Moreover, the study analysis on the portion of the preparation of financial statement in respect to the learning of IFRS the mean and the standard deviation value was found to be 3.8667 and 0.92074 respectively which indicates that the students are relatively keenly interested in learning of IFRS in order to gain the knowledge and skills that will help in preparing the financial statement. Additional on the ground of the reporting of the financial statement, the finding in respect to the reporting of the financial statement in terms of IFRS indicated the mean value as 3.5926 and the standard deviation as 1.05304 which means that the student feels learning of IFRS will help in gaining the knowledge and developing the skills for the reporting of the financial statement. Going further to the process of the financial statement, additional in respect to the analysis of the financial statement the main value was found to be 3.5926 and the standard deviation as 1.05304 , which clearly indicates that the students have the perception that by learning of IFRS content it will help in gaining the knowledge and skills for the analysis of the financial statement in the practical sense.

In the line of the discussion from the findings of this study conducted on the students, regarding the managerial decisions students believes that learning of IFRS and gaining the practical knowledge and skills has the outcome of IFRS will help them in taking the managerial decisions in the internal functioning of the company and students are very much optimistic in respect to the learning of reference towards a managerial decision in the highly relative terms, the mean and standard deviation in respect to the managerial decision was found to be 4.0370 and 0.70613 respectively. The student's perception towards financial and operational decision from the learning of IFRS indicated the mean value of 4.0296 and the standard deviation as 0.75252 , which means that the student perception towards IFRS knowledge and skills is very much positive towards the financial and operating decisions as they believe that the learning of IFRS and giving the knowledge and skills they will be outstanding in taking the financial and operating decisions within the organisation. Further in the process of the controlling the organisation the students believe that the learning of IFRS and gaining the knowledge and skills from it will help then in controlling the organisation in 


\section{Mll Macrothink}

International Journal of Accounting and Financial Reporting

ISSN 2162-3082

2021, Vol. 11, No. 2

a fruitful way, the mean and standard deviation that was indicated by the analysis of the results was found to be 3.7481 and 0.95197 respectively. Further on the adoption of IFRS by Saudi Arabia, and the standard deviation was found to be 3.7481 and 0.90371 , the students wish to know more about the IFRS because it was adopted by Saudi Arabia in 2016 because they feel that is there will get the knowledge of IFRS as a part of Curriculum then it will be beneficial to them in getting the job in the company, the job aspect of the students is the main factor in learning the IFRS as indicated in the mean and standard deviation as 4.0000 and 0.88941 respectively. The student wishes to know more about the IFRS because they believe that it will update their knowledge of accounting and also it will help then to have a career in the Global transactions and interaction in common as indicated in the study results of mean and standard deviation in the below table. Finally, the students also wish to know more about IFRS because students feel that the knowledge and skills of IFRS will help them in preparation of the Professional Examination as indicated in the study analysis of mean and standard deviation. (Refer the Table 16).

Table 16. Descriptive statistics

\begin{tabular}{|c|c|c|c|c|c|}
\hline & $\mathrm{N}$ & Minimum & Maximum & Mean & Std. Deviation \\
\hline $\begin{array}{l}\text { Knowledge and skills of IFRS } \\
\text { will help in Recording Business } \\
\text { Transactions }\end{array}$ & 135 & 1.00 & 5.00 & 3.6000 & 1.06645 \\
\hline $\begin{array}{l}\text { Knowledge and skills of IFRS } \\
\text { will help in Preparing the } \\
\text { Financial Statements }\end{array}$ & 135 & 1.00 & 5.00 & 3.8667 & .92074 \\
\hline $\begin{array}{l}\text { Knowledge and expertise of } \\
\text { IFRS will help in Reporting the } \\
\text { Financial Statements }\end{array}$ & 135 & 1.00 & 5.00 & 3.5630 & 1.01927 \\
\hline $\begin{array}{l}\text { Understanding of IFRS will } \\
\text { help in analysing the Financial } \\
\text { Statements }\end{array}$ & 135 & 2.00 & 5.00 & 3.5926 & 1.05304 \\
\hline $\begin{array}{l}\text { Understanding and expertise in } \\
\text { IFRS help in Taking Executive } \\
\text { Judgments }\end{array}$ & 135 & 2.00 & 5.00 & 4.0370 & .70613 \\
\hline $\begin{array}{l}\text { Understanding and expertise in } \\
\text { IFRS will help in Taking } \\
\text { Financial and Operating } \\
\text { Decisions }\end{array}$ & 135 & 2.00 & 5.00 & 4.0296 & .75252 \\
\hline $\begin{array}{l}\text { Understanding and expertise in } \\
\text { IFRS will help in Monitoring } \\
\text { the Organisation }\end{array}$ & 135 & 1.00 & 5.00 & 3.7481 & .95197 \\
\hline $\begin{array}{l}\text { I desire to be acquainted with } \\
\text { more about IFRS because it has } \\
\text { been adopted in Saudi Arabia }\end{array}$ & 135 & 1.00 & 5.00 & 3.7481 & .90371 \\
\hline
\end{tabular}




\begin{tabular}{|c|c|c|c|c|c|}
\hline $\begin{array}{l}\text { I want to be acquainted with } \\
\text { more about IFRS because. It } \\
\text { will help me in my Job }\end{array}$ & 135 & 2.00 & 5.00 & 4.0000 & .88941 \\
\hline $\begin{array}{l}\text { I desire to know more about } \\
\text { IFRS because It will improve } \\
\text { my understanding of } \\
\text { Accounting }\end{array}$ & 135 & 2.00 & 5.00 & 4.0370 & .95735 \\
\hline $\begin{array}{l}\text { I want to know more about } \\
\text { IFRS because Students will } \\
\text { have careers where global } \\
\text { transactions and interactions are } \\
\text { common }\end{array}$ & 135 & 2.00 & 5.00 & 4.2815 & .74965 \\
\hline $\begin{array}{l}\text { I desire to know more about } \\
\text { IFRS because It will aid in my } \\
\text { planning for specialized } \\
\text { examination }\end{array}$ & 135 & 2.00 & 5.00 & 3.9704 & .77209 \\
\hline
\end{tabular}

Source: Primary Data

\section{RQ1-Is there any need for IFRS to be introduced in the Saudi Arabian Universities?}

The analysis for the students' perception about the IFRS was analysed by using the mean and standard deviation on the 5 point scale data. The training of IFRS knowledge and skills will help in in business transaction indicated the mean value of 3.6000 and standard deviation as 1.06645, which indicates that the students are relatively eager to learn IFRS and they want to gain the knowledge and skills that will help in recording the business transactions. There is a pressing demand to integrate IFRS into the accounting curriculum in the institutes in Saudi Arabia. A good number of respondents, almost $86.7 \%$ think that knowledge of IFRS will help them get placement. Respondents are well aware of the repercussion of not knowing this uniform accounting concept. Therefore, they think it is imperative for them to learn and get converse with latest accounting technique in order to avail good opportunities in the market.

\section{RQ2- Do Saudi Arabian Graduate students have any knowledge of IFRS?}

This is the pertinent question regarding IFRS adoption is that the Students' knowledge and understanding of IFRS need to be gauged in order to properly acceptance and execution of IFRS in universities and colleges. Respondents have been asked to respond regarding their knowledge and understanding related to different concepts and terminology of IFRS. Students' were asked about their understating of Uniform Accounting World. Only 30.4\% of the students responded correctly as IFRS rests around $70 \%$ of students were unaware of this vital term of accounting. But when asked about their awareness concerning the Saudi Organization for Certified Public Accountants (SOCPA) adoption of IFRS for Listed Companies in Saudi Arabia. Fascinatingly $71.1 \%$ respondents nodded in yes but still around $28.9 \%$ respondent found to be unaware that SOCPA has decided to adopt IFRS in Saudi Arabia from 2016. When students have been asked about some fundamental differences 


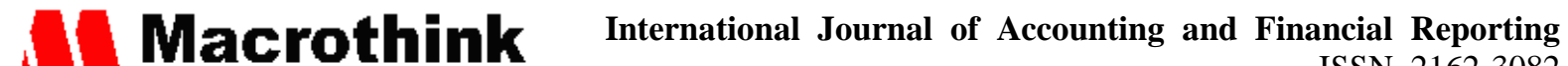 ISSN 2162-3082 2021, Vol. 11, No. 2}

between Saudi GAAP and IFRS. Surprisingly $83.7 \%$ of the respondents replied correctly while only $16.3 \%$ respondent nodded in no.

\section{RQ3- Do Saudi students have any interest in electing IFRS course in their curriculum?}

Literature has stated that with increased in the information and knowledge regarding certain things. There is generally acceptability and acceptance of change, in this aspect when students have been asked to express their enthusiasm to undergo IFRS training in future. Around 71.9 \% respondents their eagerness to take up IFRS training in future if provided while only $\mathbf{2 8 . 1 \%}$ responded in negative.

\section{RQ4- If students are enthusiastic about taking IFRS in their course, what teaching methodology would they prefer for taking up the course?}

The IFRS adoption will be fruitful only when all the stakeholders, including students, are taken into confidence. The primary strategy in this regard is to make stakeholders aware of the importance of knowledge and adoption IFRS, benefits of IFRS and future opportunities associated with it. In this study, scholars were keen to examine whether Saudi Accounting curriculum or any course includes IFRS at present. Around $85.2 \%$ of respondents have said their course curriculum include IFRS only $14.8 \%$ responded negatively saying they do not have any course relating to IFRS in their current Accounting curriculum. The reason for this positive response may be that students got confused IFRS as a topic with IFRS as a complete course. Is it essential to include IFRS as a Core course? On the question, Should educational institutes in Saudi Arabia adopt IFRS in their course curriculum or not. There was great response around 91.1\% respondents have supported that Saudi Universities should include IFRS in their curriculum which is in line with the finding of (Patro, A., \& Gupta, V. K. (2012), while only $8.9 \%$ respondents had negative opinion.

On the question whether students would you like to choose IFRS as a course in your curriculum almost large chunk of respondents around $83 \%$ responded in yes saying they would like to take IFRS as a course if introduced this is in contrast of study conducted by (Patro, A., \& Gupta, V. K. (2012), where they found that only $68.50 \%$ agree to take the course if introduced. There are many exciting finding which this study has uncovered. Like when asked how respondent interested to take up this course.48.1\% of students are interested in taking this course in PG as a core course, $7 \%$ would like to choose as an elective while $28.1 \%$ of students want this course as a project work

Based on the guidance provided by Barth, (2008), specifying how researchers should instruct students for global financial reporting, it is suggested that principle-based IFRS education be adopted as an suitable pedagogy. Also, on the basis of a past study by different researcher around the world in respect to teaching strategy for an accounting instructor that will make teaching enjoyable which will lead to delivering a more fruitful result for the students. Respondents have been asked to choose their likeness regarding teaching strategy to get more understanding of this concept. Around 50.4\% respondent has said they are like to get IFRS education through lecture method, $27.4 \%$ want it to be through seminar while only $22.2 \%$ of students want IFRS education through the case study method. Therefore, approach to IFRS 
education should be in a manner that will prepare students to face different real-life business situation and impart them enough skills and knowledge so that they will not shy away to face any business issue and challenges.

\section{RQ5- What would be the probable effect after adopting IFRS to the Saudi GAAP Accounting curriculum?}

The knowledge and skill acquired through learning IFRS will be a great help for students as after proper IFRS training their understanding of different accounting and financial concept will improve in the manifold. Their understating and looking at different accounting concept will change drastically. They will be not only able to analyse financial statements of national companies but also financial statements of the companies operating across the globe because of IFRS.The adoption of IFRS by Saudi Arabia, and the standard deviation was found to be 3.7481 and 0.90371, the students wish to know more about the IFRS because it was adopted by Saudi Arabia in 2016 because they feel that is there will get the knowledge of IFRS as a part of curriculum then it will be helpful to them in getting the job in the company, the job aspect of the students is the main factor in learning the IFRS as indicated in the mean and standard deviation as 4.0000 and 0.88941 respectively.

\section{RQ6- Are Universities in Saudi Arabia ready and well equipped to adopt IFRS to its Curriculum?}

From the finding of the current study, it can be inferred that still, universities here are in the nascent stage in terms of required knowledge, skills, expertise preparedness to adopt IFRS to the accounting curriculum. About $70 \%$ respondent exactly do not know the meaning of IFRS. About $91.1 \%$ respondent emphasise that educational institutes should adopt IFRS in their course curriculum. $32.6 \%$ of the respondents said Saudi Arabia is still not ready with sufficient IFRS trained CAs. The study revealed that $15.6 \%$ respondents got to know about IFRS through the newspaper, $25.9 \%$ and $35.6 \%$ respondent have become familiar with magazines and internet respectively while only $23 \%$ students got to know about IFRS through a classroom session

\section{Findings of the Study}

The current study has unearthed many interesting things related to International Financial Reporting Standard (IFRS) in Saudi Arabia. The study highlighted a pressing need for IFRS to be introduced in accounting curriculum as around almost $70 \%$ respondents found to be unaware of IFRS.Secondly, going further to the process of the financial statement, additional in respect to the analysis of the financial statement the primary value was found to be 3.5926 and the standard deviation as 1.05304, which indicates that the students have the perception that by learning of IFRS content it will help in gaining the knowledge and skills for the analysis of the financial statement in the practical sense. Further, the students want to know more about the IFRS as it was implemented by Saudi Arabia in 2016 because they feel that if they get the knowledge of IFRS as a part of curriculum then it will be useful to them in getting the suitable job in the company, the job aspect of the students is the main factor in 


\section{Macrothink}

International Journal of Accounting and Financial Reporting

ISSN 2162-3082

learning the IFRS as indicated in the mean and standard deviation as 4.0000 and 0.88941 respectively.

Finally, the students desire to know more about IFRS because students feel that the training, understanding and expertise of IFRS will help them prepare the professional examination, as indicated in the study analysis of mean and standard deviation.

\section{Conclusion}

When there are changes for better, all stakeholders must embrace it, then only it would be able to achieve sought result. This study has been conducted to examine stakeholders' eagerness, enthusiasm, interest, and preparedness concerning IFRS adoption in Saudi Arabia. In this connection, this research has been undertaken to check knowledge, keenness and interest of students and academicians, related to IFRS adoption in Saudi Arabia. Keeping in mind and attaining the present study's objectives, the study mainly targets, students studying accounting at Jazan region in Saudi Arabia. The study has divulged many facts related to "Uniform accounting in the world". The study has shown that despite Saudi Arabia has adopted IFRS; there are thousands of miles to go. The present study has disclosed many essential facets of IFRS adoption; some results have shown positive aspects of IFRS while others stated otherwise. There are still many aspects of IFRS which needs to be considered by all stakeholders. To achieve the sought result of IFRS, all the institution needs to embrace and adapt required change to the adoption of IFRS in Saudi Arabia. The Saudi Organization for Certified Public Accountants (SOCPA) has to lead from the front and guide all parties with regard to requirement, proper implementation and adoption of IFRS in the country. The professional training program of IFRS should be imparted to faculty members and students to avail fruitful result of IFRS in Saudi Arabia.

\section{Implications of the Study}

The findings of current research regarding the unearthing the International Financial Reporting Standards (IFRS) in the Accounting Curriculum in Saudi Arabian colleges \& universities students, will provide a benchmark for the adoption, preparation and formulation of syllabus ,and integrating IFRS with accounting curriculum in Saudi Arabian Universities. This research will also provide a base for the overall development of qualitative accounting education in universities and colleges in the country.

\section{Limitation and Future Research of the Study}

As this study has identified that IFRS is still in nascent stages in Saudi Arabia. There are a long way to go with regards to IFRS in the country. The study has selected only the Jazan region. Therefore this result cannot be generalised for whole of Saudi Arabia. The limited numbers of the respondent is also one of the limitations of the present study. Furthermore, It is advisable to conduct future research taking different respondent sections, the region with a larger sample size. Different region and sample size would give a varied result that will help in unearthing the IFRS perceptions, better preparation and implementation of IFRS adoption in Saudi Arabia. 


\section{Macrothink \\ International Journal of Accounting and Financial Reporting \\ ISSN 2162-3082 \\ 2021, Vol. 11, No. 2}

\section{Conflict of Interest}

The authors confirm that there is no conflict of interest to declare for this publication.

\section{References}

Adetula, D. T., Nwobu, O., \& Owolabi, F. (2014). International financial reporting standards and foreign direct investment in Nigeria. International Journal of Commerce, Business and Management, 3(3), 446-449.

Akisik, O. (2014). Financial reporting and foreign direct investments in Latin America. Accounting in Latin America, 41-47.

Alghamdi, S. A. (2014). Relevance of international financial reporting standards to emerging markets: evidence from saudi arabia. Arab Journal of Administrative Sciences, 21(1).

Alkhtani, S. (2012). The relevance and usefulness of IFRSs to Saudi Arabia. Journal of Administrative and Economics Science, 5(2), 21-53.

AlMotairy, O. S., \& AlTorky, K. H. (2012). A Survey of the Accounting Curriculum and IFRS in Saudi Universities: Academic Perspectives. Journal of Administrative and Economics Science, 5(2).

Alsuhaibani, A. (2012). The expected impact of IFRS adoption on Saudi Arabia based on lessons from other countries: A focus on the telecommunication Business. Procedia-Social and Behavioral Sciences, 62, 1190-1198.

Barth, M. E. (2008). Global financial reporting: Implications for US academics. The Accounting Review, 83(5), 1159-1179.

Chen, C. J., Ding, Y., \& Xu, B. (2014). Convergence of accounting standards and foreign direct investment. The International Journal of Accounting, 49(1), 53-86.

DeFond, M., Hu, X., Hung, M., \& Li, S. (2011). The impact of mandatory IFRS adoption on foreign mutual fund ownership: The role of Comparability. Journal of Accounting and Economics, 51(3), 240-258.

Deloitte. (2016). Adoption of IFRS in Saudi Arabia. Retrieved from https://2.deloitte.com/xe/en/pages/about-deloitte/articles/on-malta/adoption-of-IFRS-insa.html

Elhaj, M. R. (2019). Overview on the Convergence of US GAAP into IFRS in Saudi Arabia. Universal Journal of Accounting and Finance, 7(4), 96-105.

Gordon, L. A., Loeb, M. P., \& Zhu, W. (2012). The impact of IFRS adoption on foreign direct investment. Journal of Accounting and Public Policy, 31(4), 374-398. Retrieved from https://www.ey.com/Publication/vwLUAssets/ey-ifrs-adoption-in-kingdom-of-saudi-arabia/\$ FILE/ey-ifrs-adoption-in-kingdom-of-saudi-arabia.pdf

Mahmood, Z., Khan, A. B., ur Rehman, A., \& Atta, S. (2018). Preliminary Insights on the Adoption of International Financial Reporting Standard (IFRS) for Small and Medium 


\section{MlMacrothink}

International Journal of Accounting and Financial Reporting

ISSN 2162-3082

Enterprises (SMEs) in Pakistan. Journal of Accounting and Finance in Emerging Economies, 4(1), 95-110.

Nnadi, M., \& Soobaroyen, T. (2015). International financial reporting standards and foreign direct investment: The case of Africa. Advances in Accounting, 31(2), 228-238.

Nurunnabi, M. (2017). IFRS and Saudi accounting standards: a critical investigation. International Journal of Disclosure and Governance, 14(3), 191-206.

Nurunnabi, M. (2018). Perceived costs and benefits of IFRS adoption in Saudi Arabia: An exploratory study. Research in Accounting Regulation, 30(2), 166-175.

Okpala, K. E. (2012). Adoption of IFRS and financial statements effects: The perceived implications on FDI and Nigeria economy. Australian Journal of Business and Management Research, 2(5), 76.

Patel, B. K., \& Shah, B. M. (2015). Application and Challenges of International Financial Reporting Standard to Indian Corporate. CLEAR International Journal of Research in Commerce \& Management, 6(11).

Patro, A., \& Gupta, V. K. (2012). Adoption of International Financial Reporting Standards (IFRS) in accounting curriculum in India-An empirical study. Procedia Economics and Finance, 2, 227-236.

Razak, R. A., \& Alqurashi, R. F. (2019). Assessing the impact of the mandatory conversion to IFRS on net income in Saudi Arabia. Asia Pacific Journal of Advanced Business and Social Studies, 5(1), 65-75.

Wan Ismail, W. A., van Zijl, T., \& Dunstan, K. L. (2010). Earnings quality and the adoption of IFRS-based accounting standards: Evidence from an emerging market. Available at SSRN 1566634.

Yousefinejad, M., Ahmad, A., Salleh, F., Rahim, R. A., \& Azam, H. (2018). The Mediating Effect of Information Asymmetry on IFRS and Foreign Direct Investment. International Journal of Economics \& Management, 12(2).

\section{Copyright Disclaimer}

Copyright for this article is retained by the author(s), with first publication rights granted to the journal.

This is an open-access article distributed under the terms and conditions of the Creative Commons Attribution license (http://creativecommons.org/licenses/by/4.0/) 